\title{
Fasting Insulin in Essential Hypertension
}

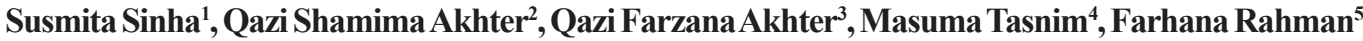

\begin{abstract}
Background: An association between essential hypertension and defective insulin secretion has been identified. Objective: To estimate fasting serum insulin level in adult male with essential hypertension to observe its relationship to hypertension. Methods: This cross sectional study was conducted in the Department of Physiology, Dhaka Medical College, Dhaka from July 2012 to June 2013. A total number of one hundred fifty male subjects were selected with age ranging from 25 to 45 years. Seventy five male essential hypertensive were enrolled from Out- patient Department of Medicine, Dhaka Medical College Hospital, Dhaka. Age matched seventy five apparently healthy males were studied as control. Fasting serum insulin level was measured by ELISA method and fasting blood glucose by glucose oxidase method. For statistical analyses, unpaired Student's ' $t$ ' and Pearson's correlation coefficient (r) tests were performed. Results: Fasting serum insulin level was significantly $(\mathrm{P}<0.001)$ higher in essential hypertensive male patients than normotensive subjects. Fasting serum insulin level shows significant positive correlation with systolic blood pressure in hypertensive patients. Conclusion: This study reveals that essential hypertension has positive and significant relationship with fasting serum insulin level.
\end{abstract}

Key-words: Essential hypertension, fasting serum insulin level, systolic blood pressure.

Bangladesh Soc Physiol. 2014, December; 9(2): 54-58 For Authors Affiliation, see end of text.

http://www.banglajol.info/index.php/JBSP

\section{Introduction}

I n Bangladesh, now-a-days a considerable number of people are suffering from essential hypertension. Morbidity and mortality from this disease is also alarming. ${ }^{1}$ Hypertension is a recognized modifiable risk factor of cardiovascular disease (CVD), stroke and end stage renal disease. The prevalence of hypertension has increased in young men than in women. ${ }^{2}$ In more than $95 \%$ of cases, a specific underlying cause of hypertension cannot be found. Such patients are said to have essential hypertension. ${ }^{3}$ Bangladesh Noncommunicable Disease (NCD) Risk Factor Survey 2010 was carried out by Bangladesh Society of

Received February 2014; Accepted September 2014
Medicine in collaboration with Directorate General of Health Services and World Health Organization in adults aged $>25$ years. According to the survey, prevalence of hypertension is $17.9 \%$ in general, $18.5 \%$ in men and $17.3 \%$ in women. There is interplay between environmental and genetic factors that contributes to the pathophysiology of essential hypertension. ${ }^{4}$ Insulin is the most potent anabolic hormone which is essential for appropriate tissue development, growth, and maintenance of whole body glucose homeostasis. ${ }^{5}$

Studies have reported relationship between elevated fasting serum insulin level and various metabolic disorders including non-insulin dependent diabetes mellitus, dyslipidemia and 
hypertension. ${ }^{6}$ Elevated levels of fasting serum insulin was found associated with increased risk of cardiovascular disease. Epidemiological studies have identified an association between hyperinsulinemia (elevated fasting and postprandial insulin levels) and hypertension. ${ }^{7-9}$

In contrast some investigators observed no significant difference between the healthy subjects and essential hypertensive patients in regard to fasting serum insulin level. ${ }^{10-11}$

So, the precise nature of the relationship between fasting serum insulin level and essential hypertension remains still obscure. Therefore, this study has been designed to assess the fasting serum insulin level in adult male with essential hypertension.

\section{Methods}

This cross sectional study was conducted in the Department of Physiology, Dhaka Medical College, Dhaka from July 2012 to June 2013. Protocol of this study was approved by Ethical Review Committee of Dhaka Medical College. Seventy five male of 25-45 years of age with essential hypertension participated in this study. They were selected from Out-patient Department of Medicine, Dhaka Medical College Hospital, Dhaka. Age matched seventy five apparently healthy males studied as control group for comparison. All the subjects were free from any endocrine disorder, renal disease, psychic disorder and any hereditary disease.

After selection of subjects, the objectives, nature, purpose and benefit of the study were explained to the subjects in details. Informed written consent was taken from all the participants. The subjects were advised to attend the laboratory in the Department of Physiology of Dhaka Medical College, Dhaka between 8 AM to 10 AM. After taking detail personal history, drug history, past medical history, all clinical examinations were done, Then anthropometric measurement including height, weight and BMI were taken. 5 $\mathrm{ml}$ blood from all subjects was collected after an overnight fast (at least 12 hours). All the information was recorded in a data schedule.

Fasting serum insulin level was assessed by Enzyme Linked Immunosorbent Assay (ELISA) and fasting blood glucose level was estimated by glucose oxidase method in the laboratory of Department of Physiology and Molecular Biology, BIRDEM Academy, Dhaka.

Data were expressed as mean and standard error (SE). For statistical analyses, unpaired Student's ' $t$ ' and Pearson's correlation coefficient ( $r$ ) tests were used. All data were analyzed by SPSS 13.5 version.

\section{Results}

General characteristics of the subjects are presented in Table I.

Table I: General characteristics of the subjects in both groups $(\mathrm{n}=150)$

\begin{tabular}{lcc}
\hline Parameters & $\begin{array}{c}\text { Control } \\
(\mathrm{n}=75)\end{array}$ & $\begin{array}{c}\text { Hypertensive } \\
\text { patients } \\
(\mathrm{n}=75)\end{array}$ \\
\hline Age (years) & $33.53 \pm 0.78$ & $36.43 \pm 0.80$ \\
Height $(\mathrm{cm})$ & $165.53 \pm 0.60$ & $164.67 \pm 0.60$ \\
Weight $(\mathrm{kg})$ & $60.49 \pm 0.51$ & $61.40 \pm 0.40$ \\
BMI $\left(\mathrm{kg} / \mathrm{m}^{2}\right)$ & $22.11 \pm 0.20$ & $22.69 \pm 0.19$ \\
$\mathrm{SBP}(\mathrm{mmHg})$ & $116.73+0.77$ & $142+0.58^{*}$ \\
DBP $(\mathrm{mmHg})$ & $73.47+0.57$ & $90.93+0.28^{*}$ \\
\hline
\end{tabular}

Data were expressed as Mean \pm SE. Unpaired Student's ' $t$ ' test was performed to compare between groups. $* \mathrm{P}<0.001$

Systolic and diastolic blood pressure were higher in hypertensive patients.

Fasting blood glucose level was almost similar in both essential hypertensive patients and controls.

The mean $(+\mathrm{SE})$ fasting serum insulin level in hypertensive patients was higher than that of controls, which was statistically highly significant $(\mathrm{p}<0.001)$ (Table II). 
Table II : Fasting serum insulin level and fasting blood glucose level in both groups $(n=150)$

\begin{tabular}{lcr}
\hline Parameter & $\begin{array}{c}\text { Control } \\
(\mathrm{n}=75)\end{array}$ & $\begin{array}{c}\text { Hypertensive } \\
\text { patients }(\mathrm{n}=75)\end{array}$ \\
\hline $\begin{array}{l}\text { Fasting serum } \\
\text { insulin level }\end{array}$ & $10.05 \pm 0.51$ & $21.11 \pm 1.06^{*}$ \\
$\begin{array}{l}\text { (iIU/ml) } \\
\text { Fasting blood } \\
\text { glucose level } \\
(\mathrm{mmol} / \mathrm{L})\end{array}$ & $5.07+0.06$ & $5.37+0.07$ \\
\hline
\end{tabular}

Data were expressed as Mean \pm SE. Unpaired Student's ' $t$ ' test was performed to compare between groups. ${ }^{*}=$ Significant at $\mathrm{P}<0.001$

Correlation analysis between fasting insulin level and both systolic and diastolic blood pressure shows positive correlation in hypertensive patients but it was statistically significant for systolic blood pressure only. But there was almost no correlation between these two parameters in control subjects. (Figure $1 \& 2$ )

In addition almost no correlation was found between glucose level and fasting insulin level in both hypertensive and control subjects. (Figure 3)

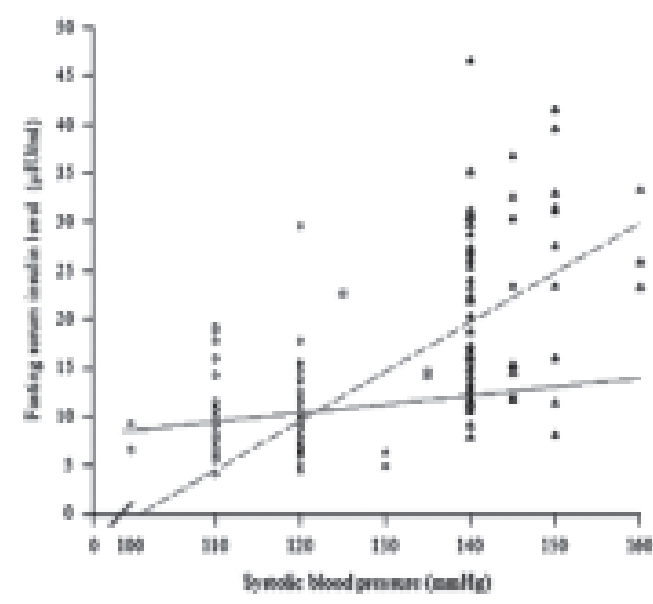

Figure 1 : Correlation between systolic blood pressure and fasting insulin level in control $(n=17)$ and in hypertensive patients $(\mathrm{n}=75)$

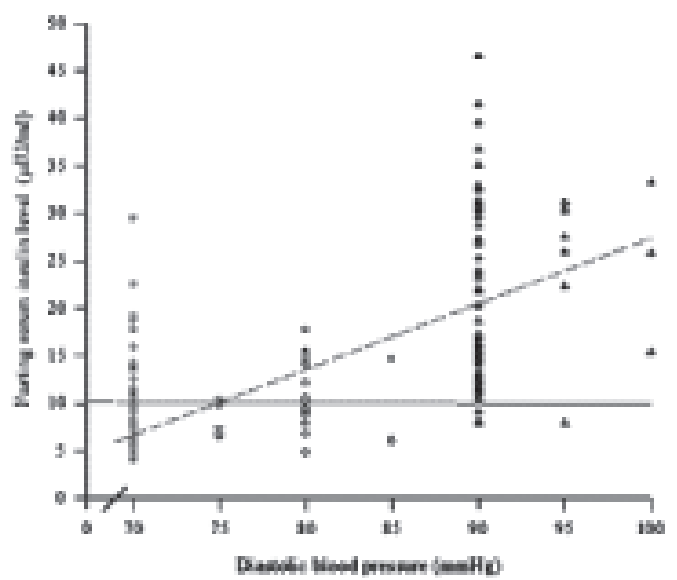

Figure 2: correlation between diastolic blood pressure and fasting insulin level in control $(=75)$ and in hypertensive patients $(n=75)$

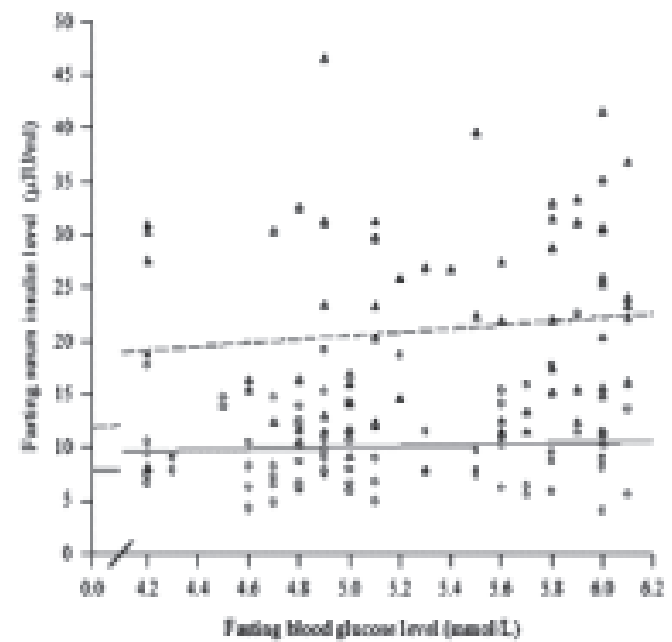

Figure 3 : Correlation between fasting blood glucose level and fasting insulin level in control $(n=75)$ and hypertensive patients $(n=75)$

\section{Discussion}

In the present study, fasting serum insulin level in control was almost within normal range and also similar to those reported by the various investigators from different countries. ${ }^{6-9}$

The mean value of fasting serum insulin level was significantly higher in adult male with essential hypertension when compared with that 
of controls. Systolic blood pressure and diastolic blood pressure show positive correlation with insulin but was significant only with systolic blood pressure. This finding is consistent with the findings of some other investigators of other countries. ${ }^{6-9,} 12$

Elevated insulin level may alter blood pressure as it has effects on the sympathetic nervous system and renal sodium reabsorption. It has been suggested that sympathetic over activity may lead to structural changes in the microvasculature. Which ultimately increases blood pressure and decreases peripheral glucose uptake. $^{6-9}$

Again, essential hypertensive subjects have significant defect in activating the insulin receptor. There is decreased insulin action on insulin receptor (IR) which reduces the activation of receptor tyrosine kinase. As a result, decrease in receptor Autophosphorylation and tyrosine phosphorylation of IRS-1. Also, there is decrease in activation of phosphatidyl inositol (PI) 3kinase, a subunit of IRS-1. This IRS-1 causes decrease glucose transport to skeletal muscles. ${ }^{12}$

In the present study, fasting serum insulin level is increased in adult male subjects with essential hypertension and essential hypertension has positive correlation with fasting serum insulin level. Whereas no correlation was found between insulin level and blood pressure in the control subjects. This finding supports the relationship between insulin level and elevated blood pressure in hypertensive subjects which may be linked to the defective mechanism in insulin secretion. But the exact mechanism is not elucidated as the insulin receptor activity and serum catecholamines level were not assessed in the study.

\section{Conclusions}

This study concludes that fasting serum insulin level is elevated in adult male subjects with essential hypertension which has strong relationship to elevated blood pressure level.

\section{Authors affiliations}

1. *Susmita Sinha, Assistant Professor, Department of Physiology, Eastern Medical College, Comilla. Email: scobidu_9999@yahoo.com

2. Qazi Shamima Akhter, Professor and Head, Department of Physiology, Dhaka Medical College, Dhaka.

3. Qazi Farzana Akhter, Assistant Professor, Department of Physiology, Uttara Adhunik Medical College, Dhaka.

4. Masuma Tasnim, Assistant Professor, Department of Physiology, Ad din Women's Medical College, Dhaka.

5. Farhana Rahman, Assistant Professor, Department of Physiology, Delta Medical College, Dhaka.

*For correspondence

\section{References}

1. Uddin MN, Ali MZ, Jahan NWB, Rashid MA, Sultan MK, Hoque MA, et al. Study of serum insulin level in hypertensive patients. Cardiovasc J. 2011; 4 (1):13-16.

2. Kearney PM, Whelton M, Reynolds K, Whelton PK, He J. Global burden of hypertension: analysis of world-wide data. Lancet. 2005; 365: 217-223.

3. Boon NA, Colledge NR, Walker BR, Hunter JAA. Davidson's Principles and Practice of Medicine. 20th ed. India: Elsevier Limited; 2006.

4. Islam AKM, Majumder AAS. Hypertension in Bangladesh-a review. Indian Heart J. 2012; 6403: 323 .

5. Pessin JH, Saltiel AR. Signaling pathways in insulin action: molecular targets of insulin resistance.J Clin Invest. 2000; 106(2): 165- 169.

6. Haffner SM, Valdez RA, Hazuda HP, Mitchell BD, Morales PA, Stern MP. Prospective analysis of the insulin-resistance syndrome (syndrome $\mathrm{X}$ ). Diabetes 1992, 41: 715-722.

7. Welborn TA, Breckenridge A, Dollery CT. Seruminsulin in essential hypertension and in peripheral vascular disease. Lancet 1966; 1:1336-1337.

8. Penesova A, Cizamarova E, Belan V, Blazicek P, Imrich R, Vlcek M, et al. Insulin resistance in young, 
lean male subjects with essential hypertension. J Hum Hypertens. 2011; 25: 391-400.

9. Kronenberg F, Rich SS, Sholinsky P, Arnett DK, Province $\mathrm{ME}$, Myers $\mathrm{RH}$, et al. Insulin and hypertension in the NHLBI family heart study. Am J Hypertens. 2000; 13: 240-250.

10. Baba T, Kodama T, Tomiyama T, Fujita N, Takebe $\mathrm{K}$. Hyperinsulinemia and blood pressure in nonobese middle-aged subjects with normal glucose tolerance. Tohoku J Exp Med. 1991; 165: 229-235

11. Every NR, Boyko EJ, Keane EM, Marshall JA, Rewers M, Hamman RF. Blood pressure, insulin, and C-peptide levels in San Luis Valley, Colorado. Diabetes Care 1993;16:1 543-1550.

12. Sloniger JA, Saengsirisuwan V, Diehl CJ, Dokken BB, Lailerd N, Lemieux AM, et al. Defective insulin signaling in skeletal muscle of the hypertensive TG (mREN2) 27 rat. Am J Physiol Endocrinol Metab. 2005; 288: 1074- 1081. 